Document downloaded from:

http://hdl.handle.net/10251/154806

This paper must be cited as:

Boni Aristizábal, A.; Millan Franco, GF.; Millan Franco, MA. (2018). When Collectivity Makes a Difference: Theoretical and Empirical Insights from Urban and Rural Communities in Colombia. Journal of Human Development and Capabilities. 19(2):216-231. https://doi.org/10.1080/19452829.2017.1412408

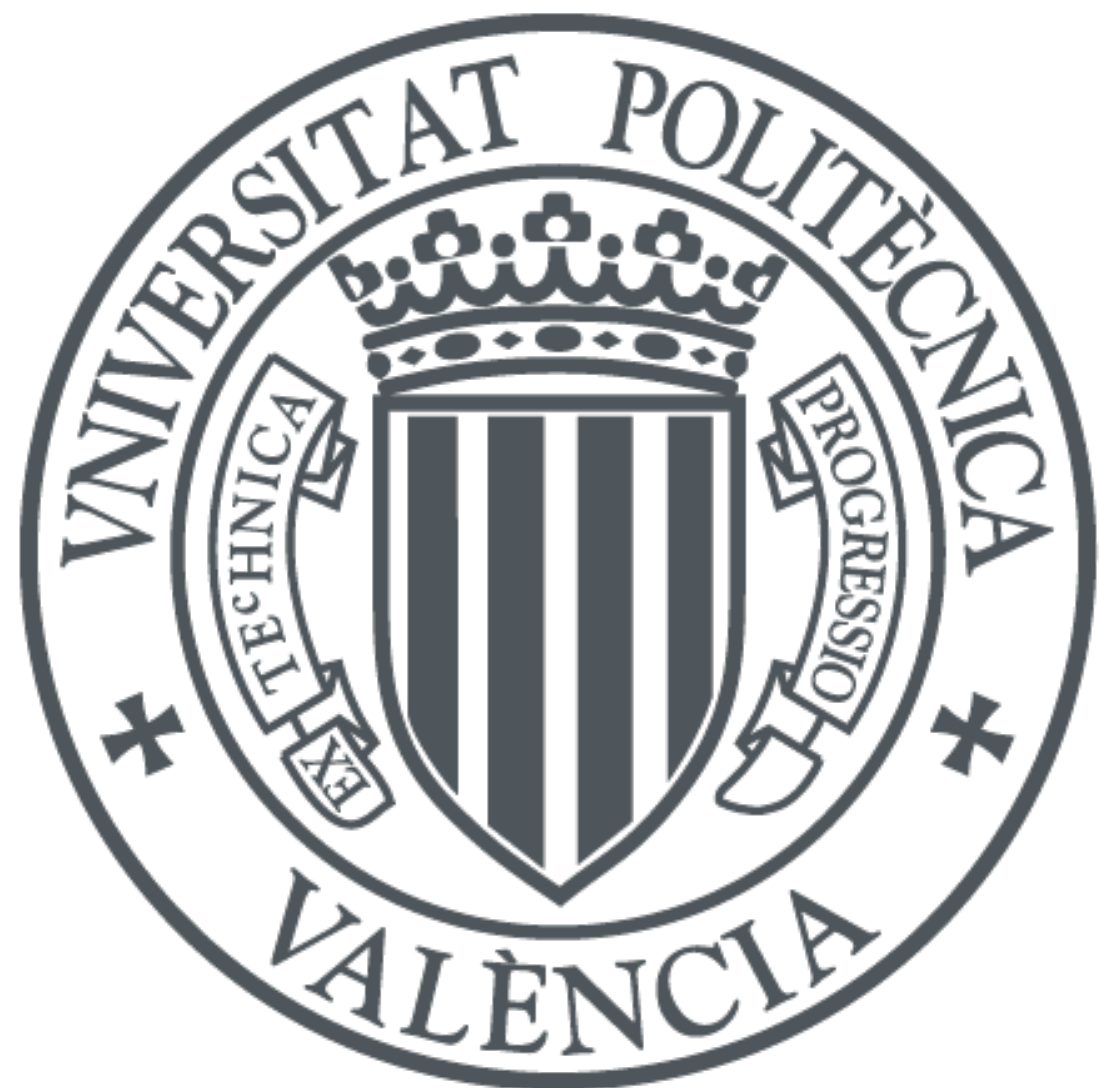

The final publication is available at

https://doi.org/10.1080/19452829.2017.1412408

Copyright Taylor \& Francis

Additional Information 


\title{
When collectivity makes a difference: Theoretical and empirical insights from urban and rural communities in Colombia
}

\author{
Alejandra Boni, Gynna F. Millán Franco \& María Alejandra Millán Franco \\ To cite this article: Alejandra Boni, Gynna F. Millán Franco \& María Alejandra Millán \\ Franco (2017): When Collectivity Makes a Difference: Theoretical and Empirical \\ Insights from Urban and Rural Communities in Colombia, Journal of Human \\ Development and Capabilities, DOI: 10.1080/19452829.2017.1412408
}

To link to this article: https://doi.org/10.1080/19452829.2017.1412408

\section{Introduction.}

There is no single definition of what a community is; nor is there a general consensus of what reasons people have to value being part of a community. Tonon (2012:21-22) describes some of the interpretations of the significance of community. In the ancient world, communis meant 'sharing a load', and comunitas was 'the group of people who are the members of the community'. Other interpretations have highlighted the relevance of intersubjectivity and sharing (Lo Biondo, 1999), networks of relations that produce mutual support (Sarason, 1974), or the importance of citizenship as a way to identify and characterise members of a community (Cortina, 2005).

Other authors have studied the psychological factors that try to explain the sense of belonging to a community. For instance, McMillan and Chavis (1986) highlight that the feeling of membership, the capacity the group have to influence, the fulfilment of the needs and shared emotional connections of the members, can be elements that explain the sense of forming part of a community.

This particular view of the sense of community implies that community may occur in various spaces: not only geographical spaces, where people share a territory, but also where people gather only to share interpersonal relations, such as immigrant communities or professional organisations (Ramos-Vidal and Maya-Jariego, 2014) or even virtual communities, which do not require face-to-face interaction and are independent of people's geographical position (Maya-Jariego, 2004). From this, it can be said that the sense of community is deeply contextual and needs to be assessed in different communities, both local and relational, in order to be developed in practical 
and theoretical terms (Hills, 1996 quoted in Ramos-Vidal and Maya-Jariego, 2014: 170).

In this paper we would like to explore the contribution of the capability approach literature to describe and interpret two main questions: 1) What does it mean for people to be part of a community? And 2) How are the social and environmental characteristics of where the community is located relevant to understand the implications of being part of a community?

To explore these two questions, we have defined three sub-questions that are linked with key elements of the capability approach literature: 1) What are the capabilities and functionings that people consider valuable when being part of a community? 2) To what extent do personal, social and geographical conversion factors boost or limit the exercise of capabilities and functionings of the people that belong to a community? And

3) To what extent can we observe collective capabilities and collective agency?

The structure of the paper is as follows: in the next section, we will explain in more detail the above elements of the capability approach. Then, we will give an overview of the context where the two communities are established. After this, we will explain the methods used in our research. Subsequently, we will present the results of our research and discuss the implications for the study of communities and for the capability approach theory. Finally, we conclude with some key insights from our research.

\section{Elements of the capability approach used for the analysis}

First of all, in order to examine communities under the lens of the capability approach, we have selected a group of elements that constitute the core of the approach (Robeyns, 2016): capabilities and functionings. The first are defined by Sen (1999:87) as the substantive freedoms (also real freedoms or opportunities) to lead the kind of life that people value. Functionings are the activities that people perform and that are valued by them. The approach emphasises the importance of assessment by the people themselves, in regard to the capabilities as well as the functionings.

The second group of elements we want to explore are the conversion factors. As the capabilities theory suggests, capabilities and functioning are mediated by personal (i.e., gender, status, race, intelligence, personal abilities, etc.), social (i.e., public policies, social norms, gender roles, social hierarchies, power relations, etc.), and environmental (i.e., climate, geographical conditions, etc.) conversion factors (Robeyns 2005). These 
three factors, plus our own personal history, determine our ability to convert commodities or resources into capabilities and functionings (Sen, 1999). The concept of conversion connects individual lives to social and political arrangements and the historical context in order to illuminate social norms (of race, gender, class, and so on), and how they shape our everyday lives and our capacity to take advantage of opportunities. We need information about each person's bundle of resources and commodities (their means to achieve), the personal and social conversion factors, which shape their capabilities (their freedoms to achieve) and their choices that convert capabilities into actual achievements (Boni and Walker, 2016).

Consequently, in using the idea of conversion factors to explore communities, our guiding question has been: To what extent do personal, social and geographical conversion factors boost or limit the exercise of capabilities and functionings of the people that belong to a community?

The third element of the capability approach we take into consideration for this analysis is the idea of agency. If capability is the freedom of opportunity, agency is the freedom of process. Agency refers to the ability of the individual to pursue and achieve the objectives they value. An agent is 'someone who acts and makes change happen' (Sen 1999). As Deneulin $(2014,27)$ explains, 'well-being depends not only on what a person does or is, but on how [author's emphasis] she achieved that functioning, whether she was actively involved in the process of achieving that functioning or not'. Crocker and Robeyns $(2010,6)$ helpfully indicate that individuals should not only exercise their agency by shaping or determining their own lives, but also by exercising joint agency, in this way communities can and should select, evaluate and trade-off capabilities, functionings and other normative considerations. What is important is that people individually and collectively conduct their lives, sometimes realising or helping to realise each other's goals, sometimes by forming joint interventions and exercising collective agency.

As we can see, this interpretation of agency is extremely relevant when we approach communities, which leads us to an extensively discussed area in the capability approach community, that of the idea of collective capabilities (Ibrahim, 2006). What is the constitutive element of a collective capability? Is it the aggregation of individual capabilities, or is it a capability that can be achieved socially as a result of social interaction (Comim and Carey, 2001)? 
As we have indicated above, quoting Crocker and Robeyns (2010), this debate on collectivity as a subject could also be applied to the idea of collective agency. Furthermore, this aspect is stressed by Ibrahim (2006: 405) who argues that, in contrast to individual agency, where a person 'individually' pursues his or her own perception of the good, through acts of collective agency the individual can pursue this perception of the good collectively, by joining or participating in a group with similar goals (Ibrahim, 2006: 405).

All these key elements of the capability approach have been applied in the analysis of two Colombian communities. The first is an urban community in Medellín, Colombia's second largest city. It is situated on the steep green slopes of el Cerro Pan de Azucar, above Medellín's bustling city centre. Medellín is geopolitically divided into 16 Comunas and this community is located in Comuna 8. Comuna 8 has been home to thousands of victims of Colombia's internal armed conflict. Internally displaced migrants bought vacant plots of land and began the collective construction of homes, aqueducts, roads and schools. Together, they built their barrios (neighbourhoods) more than 16 in Comuna 8 alone - that straddle the border between the urban and the rural, the legal and the informal (Greenwood, 2016). The second community is a Zona de Reserva Campesina (hereafter ZRC, which stands for Peasant Farmer Reserve Zone, in Spanish) in the Cabrera municipality, in the Department of Cundinamarca. Cabrera is a rural community with a strong tradition of agrarian struggles to gain access to land titles. It is also a productive community, near to an environmentally protected area and relatively close to Bogotá, the capital of Colombia.

\section{The context}

\section{Colombia}

Colombia has historically been characterised as a country with deep social inequalities and high levels of political and economic exclusion, which have worsened in recent years (for example, the Gini coefficient rose from 0.47 to 0.57 between 1990 and 2013). This exclusion is the basis for the protracted armed conflict which has afflicted the country, involving the state, paramilitary forces, and guerrilla groups for fifty-two years. 
According to Amnesty International (AI, 2016), the conflict has caused 6.6 million victims of forced displacement, more than 45,000 victims of forced disappearance and approximately 263,000 conflict-related killings; the vast majority of victims have been civilians.

The conflict coincides with the advancement of a neoliberal development model in the country that began in the $90 \mathrm{~s}$ and has now been consolidated. The first stage, related with the implementation and increase of agro-industrial crops, was carried out from 1993 to 2003, approximately. It corresponded with a sharp increase in paramilitary groups, forced displacement and massacres, forced disappearances, torture, etc. A second stage, which can be placed between 2003 and the present day, and involves the governments of the Uribe and Santos administrations, is characterised by the advance of mining on a large scale, supported by public policies that promote the development in the mining sector through private investment (Unidad de Planeación Minero-Energética, 2012). In this context, policies have been the basis of important conflicts arising from divergent interests and values between communities, government and businesses (CINEP, 2012). As with the advance of agro-business, mining progress has been accompanied by very high levels of violence (Massé and Camargo, 2012).

On the other hand, in 2003, under the Uribe government, negotiations began with paramilitary groups to bring about their demobilisation, aiming towards the reconciliation and reinsertion of members of paramilitary structures, revealing the truth and making reparations to the victims, peacemaking, and democracy building. After demobilisation, a large number of people who were former members of these structures regrouped into what are now known as emerging criminal gangs, a hybrid between mafias and gangs of common criminals. They use violence as a strategy to consolidate strategic corridors for drug trafficking and to promote the establishment of the extractive industry in the country (Belda-Miquel et al., 2016). These groups threaten, persecute and kill defenders of human rights, land claimants, and opposition leaders, among others (CINEP, 2012).

In October 2016, and following four years of intense negotiations between the government and the FARC guerrilla group, President Santos announced the signing of a peace agreement and the Colombian people were asked to endorse it in a national plebiscite. Surprisingly, Colombian citizens rejected the agreement by a tiny margin 
$(0.4 \%)$, causing public anger, not only at the result, but also due to the very low number of voters.

This distrust the Colombians have towards their political leaders manifests in a special way in the communities. On the one hand, as has been said previously, community leaders continue to be killed. In the year of the plebiscite alone, 80 activists and defenders of human rights were assassinated (Amnesty International, 2017). On the other hand, the development plans devised by central, departmental and even local governments, despite advocating citizen participation, in practice do not meet the needs of the communities. For these reasons, the populace has taken on the role of building local alternatives that provide solutions to their problems from their perspectives and in their everyday lives. As we will see throughout this article, in the midst of a context of hostility and violence towards their leaders, the communities continue to design their development alternatives as a way of vindicating their rights as citizens.

\section{Medellín}

Medellín is Colombia's second largest city. During the decade of the 80s, Medellín made it into the international headlines for being top of the list of the most dangerous places to live on earth. Murder rates were extremely high (approximately 380 for every 100,000 people, in 1991) as a result of it being the capital of drug trafficking and home to Pablo Escobar's infamous cartel. The city was the setting for some of the deadliest massacres perpetrated by paramilitary groups, guerrillas and the state in the midst of a national anti-drugs war, and dialogues between paramilitary groups and the state. What is known as "Operación Orion" in Comuna 13, was one of these massacres, occurring in an urban environment and resulting in more than 70 'disappeared' people and hundreds more displaced within the same city. The police and the national army undertook this military operation and their actions led to a deep distrust of the people towards their national government as a provider and guardian of human safety. Exceptionally, after 2004, Medellín began a process of urban transformation. A government with progressive public policies and a great deal of political will, decided to rebuild trust by investing in a new kind of social infrastructure backed by mobility projects such as multimodal transport (metro, BRT, metrocables and tramways). Today, after 13 years, Medellín has completely changed its global image and is now the recipient of 
international prizes for its unique approach to urban development with a strong social focus. In 2013, Medellín was heralded as "the most innovative city in the world" by the Urban Land Institute. However, this narrative of urban transformation at the international level is not the narrative of transformation of territory with which the urban communities of Medellin identify themselves. Apart from the distrust towards the local development policy already mentioned as a common pattern in the Colombian context, the particular case of the communes is the discontent they have with how the city is marketed internationally. This conforms, according to the community perspective, to a globalised logic driven by economics, rather than one that responds to the local social context.

\section{Comuna 8}

Medellín is divided in 16 Comunas and, along with Comuna 13, and Comunas 1 and 2, Comuna 8 was one of the most violent urban areas of Medellin. It is located in the east of the city centre, which makes it an attractive place to live for those who earn their living working in the city. The history of Comuna 8 is relatively short; its settlement began during the decade of the 40s. Its urban development has been extensively marked by the Colombian armed conflict, as many of its residents have been victims of forced displacement; not only on a national and departmental scale, but also on an intra-urban level, which was the mode of displacement in Medellín in early 2000. The form of settlement of the commune has also responded to the challenges and geographical risks in which it is located. Thus, neighbourhoods that are located at the bottom of the slope and closest to the city centre enjoy greater access to public services and transport links to the rest of the city. Neighbourhoods starting to emerge in the middle of the slope are becoming more consolidated, thanks to the expansion of the city and the need to provide housing in the area. Officially, Comuna 8 comprises 16 districts, but through community mapping and the constant oversight of the slope on the part of its inhabitants, the emergence of 18 more districts have been detected, although they remain unrecognised by the local government. This, coupled with the constant threat of eviction, has caused highly political work groups to form and elaborate innovative speeches that go beyond dissent and propose alternatives to promote development of a more just and equitable city. The leaders of Comuna 8 are respected and admired at the 
city level precisely because of their struggle in challenging the neoliberal development of the territory.

\section{Cabrera and the $Z R C$}

The municipality of Cabrera was established around the year 1910, and is located in the department of Cundinamarca, $144 \mathrm{~km}$ from the city of Bogotá. Cabrera is part of the province of Sumapaz, the site of one of the largest moorlands in the world (el Páramo), with great biological, ecological and genetic diversity (SINPEAGRICUN, ILSA, INCODER, 2013).

As in other parts of Colombia, Cabrera has suffered continuous episodes of violence that begun in the 50s and continue into the present, with the presence of guerrillas in the Municipality. However, Cabrera is also well known for the actions of its peasants, fighting and struggling to defend their rights to own and use land, as well as the protection of natural resources. In 2000, the municipality was formally constituted as a ZRC, which, for the peasants of Cabrera, has meant support for the organisation and consolidation of their territory. The ZRC comprises 44,000 hectares and a population of 5,377 inhabitants, of whom 4,218 are located in rural areas and 1,159 in urban areas. It is one of the peasant reserve zones that covers an entire territory, including both the town and the municipality (Velandia, 2015).

The ZRC is a legal category that was created in response to peasants' demands and includes, among others, principles such as the equitable distribution of land and the recognition of peasants as distinct political subjects. When Cabrera was established as a ZRC, it had to develop a Sustainable Development Plan, which was updated in 20112012. As discussed in the sections that follow, it is through this plan where the communitarian leaders of Cabrera express their commitment towards land conservation and promote sustainable productive projects for the protection and preservation of both the territory and its inhabitants. (SINPEAGRICUN, ILSA, INCODER, 2013).

\section{Research methods}

This article is based on the findings of a qualitative case study of research carried out in 2016. One of the authors had a six-month experience of intense fieldwork in Comuna 8, 
while another was in contact with the community of Cabrera, conducting interviews during two separate field visits.

During the research, primary information was gathered in 11 semi-structured interviews with key actors: 7 belonging to Cabrera and 4 to Comuna 8. In Table 1, we present some of the key characteristics of the interviewees.

\begin{tabular}{|c|c|c|c|c|c|c|}
\hline Code & Community & Age & Gender & $\begin{array}{l}\text { Level of } \\
\text { studies }\end{array}$ & Origin & $\begin{array}{c}\text { Leadership } \\
\text { position }\end{array}$ \\
\hline $\mathrm{C} 1 \mathrm{M}$ & Cabrera & $\begin{array}{l}70- \\
80\end{array}$ & M & $\begin{array}{c}\text { No formal } \\
\text { studies }\end{array}$ & $\begin{array}{c}\text { Grew up in } \\
\text { Cabrera }\end{array}$ & $\mathrm{Y}$ \\
\hline $\mathrm{C} 2 \mathrm{~F}$ & Cabrera & $\begin{array}{l}40- \\
50\end{array}$ & $\mathrm{~F}$ & $\begin{array}{c}\text { No formal } \\
\text { studies }\end{array}$ & Nearby town & $\mathrm{N}$ \\
\hline $\mathrm{C} 3 \mathrm{M}$ & Cabrera & $\begin{array}{l}30- \\
40\end{array}$ & M & $\begin{array}{c}\text { No formal } \\
\text { studies }\end{array}$ & Cabrera & $\mathrm{Y}$ \\
\hline $\mathrm{C} 4 \mathrm{~F}$ & Cabrera & $\begin{array}{l}30- \\
40\end{array}$ & $\mathrm{~F}$ & University & $\begin{array}{c}\text { Another } \\
\text { Department }\end{array}$ & $\mathrm{Y}$ \\
\hline $\mathrm{C} 5 \mathrm{M}$ & Cabrera & $\begin{array}{l}40- \\
50\end{array}$ & M & University & Cabrera & Y \\
\hline C6M & Cabrera & $\begin{array}{l}40- \\
50\end{array}$ & M & $\begin{array}{c}\text { No formal } \\
\text { studies }\end{array}$ & Cabrera & Y \\
\hline $\mathrm{C} 7 \mathrm{~F}$ & Cabrera & $\begin{array}{l}40- \\
50\end{array}$ & $\mathrm{~F}$ & Primary & Another town & $\mathrm{N}$ \\
\hline $\mathrm{C} 81 \mathrm{~F}$ & Comuna 8 & $\begin{array}{l}60- \\
70\end{array}$ & $\mathrm{~F}$ & Secondary & $\begin{array}{c}\text { Another } \\
\text { Department }\end{array}$ & $\mathrm{Y}$ \\
\hline $\mathrm{C} 82 \mathrm{M}$ & Comuna 8 & $\begin{array}{l}40- \\
50\end{array}$ & M & University & Medellín & Y \\
\hline $\mathrm{C} 83 \mathrm{~F}$ & Comuna 8 & $30-$ & $\mathrm{F}$ & University & Medellín & $\mathrm{Y}$ \\
\hline
\end{tabular}




\begin{tabular}{|c|c|c|c|c|c|c|}
\hline & & 40 & & & & \\
\hline C84F & Comuna 8 & $\begin{array}{c}30- \\
40\end{array}$ & F & Secondary & $\begin{array}{c}\text { Another } \\
\text { Department }\end{array}$ & Y \\
\hline
\end{tabular}

Table 1: Key characteristics of the interviewees

It is important to note that the majority of the interviewees - and all of those from Comuna 8-act in leadership roles in their communities, and that all of them belong to local organisations. So, our case especially considers the voices of people that are participating in organisations and have responsibilities for their constituencies. All the interviewees gave their personal consent to be interviewed and their anonymity has been respected.

Primary information has been complemented with secondary information. We reviewed the Plan de Mejoramiento Integral de Barrios (Comprehensive Neighbourhood Improvement Plan), a communitarian Plan produced by several members of communitarian organisations in Comuna 8, and the Plan de Desarrollo Sostenible de la Zona de Reserva Campesina de Cabrera (Sustainable Development Plan of the Peasant Farmer Reserve Zone of Cabrera), in which some of the interviewees have been actively involved. Furthermore, in the case of Comuna 8, one of the co-authors of this paper, conducted participant observation, and some of her field notes have been incorporated in the analysis.

\section{The case of Comuna 8}

All respondents agree that being part of the community gives them valuable capabilities related to a more critical and comprehensive reading of the context of where they are, allowing them to make proposals, increase their autonomy and recognise themselves as agents of change.

However, not all capabilities are related to the cognitive aspect; one of the great contributions of participating in the community are shared emotions and feelings. On the one hand, this produces a sense of emotional well-being (I am recognised, I feel happy or I find a beautiful life force) and, on the other hand, emotions and feelings are 
triggers for community participation: It's like finding the dynamite, I light up like a light bulb, also, you can see that you form part of the process, that you are taking part (C82M).

There are also very clear examples of collective capabilities, understood as capabilities that can only be acquired in collective action (Ibrahim, 2006). This quote from one of the women leaders shows how, through community relations, activists build their capability to see themselves as political subjects: "you become aware of the quarrels, the recommendations [...] having all those people who helped educate me around [...] we as activists have to think of ourselves as political subjects [...] when people make demands on you it is because this person, who really loves you, knows what you can offer them" (C84F).

In the case of this community, the capability to see themselves as political subjects has to do with a change in their development vision, from the satisfaction of basic needs, to guaranteeing human rights. In the early years of community work (1980-90), people called for working together to obtain water, sanitation, social facilities, roads, etc. In recent years, they are demanding economic and social rights, they perform advocacy work and promote social mobilisation.

In this sense, as an example of the most political functionings that community actions have produced, we find the development of the Plan de Mejoramiento Integral de Barrios (Comprehensive Neighbourhood Improvement Plan) and the Consulta Popular (Popular Consultation). The content of the Plan can be understood as a reaction to a social conversion factor that appears clearly in Comuna 8, which is the kind of public urban planning policies proposed by the municipality of Medellín: urban megaprojects, tall buildings, mobility systems, etc. The inhabitants of Comuna 8 consider that the official urban planning policy does not recognise the diversity of the modes of occupation in which the territory has been developed and it is now further endangering their right to remain in it.

The community plan was endorsed massively by the inhabitants of Comuna 8 in a Popular Consultation. However, the municipality's response has been to disable these demands, including the plan as part of its public policy but without a budget. This dynamic has been a driver for another capability: the capability to be in resistance, which we identify as another collective capability. It is not passive resistance, but purposeful resistance. As one of the leaders says: "The community is tired, we don't 
want to continue to have our rights violated ... we convert our rights into resistance, awareness, proposals" (C84F).

To understand both the Community actions and the municipal policies is important in order to refer to the environmental conversion factors. As presented above, Comuna 8 occupies a physical space at various levels; the bottom is the closest to the city centre and is the area most consolidated with services and infrastructure. As you climb, urbanisation has occurred in a more informal manner. The highest area is the one with the most precarious settlements and, in some places, lack water and sanitation. In addition, according to official planning, it is very difficult to supply water to areas that are above $1,800 \mathrm{~m}$, and they are also more exposed to risks from environmental disasters.

It is the upper part of Comuna 8 that has a stronger tradition of resistance and advocacy. It is no coincidence that it is also the location of the house of Jairo Maya (one of the Comuna 8 activists, who passed away in 2016), which was the physical space where the community came together to develop the Plan and the Public Consultation. The fact that the leaders of Comuna 8 meet in this house is unusual. As described above, its mountainous characteristics and the lack of means of transportation and physical infrastructure to connect the different neighbourhoods of Comuna 8 , makes interneighbourhood community meetings scarce; however, when they do occur they are very powerful, and it is in these areas where the collective capabilities are enhanced.

These collective capabilities are developed through the exercise of collective agency as defined by Crocker and Robeyns $(2010,6)$. It is in these community spaces where people participate, prioritise and define their vision of the public good. As noted by one interviewee, it is "an exercise of participation for the construction of the territory [...] the community feels they need to assert their presence, to be understood as citizens" $(\mathrm{C} 83 \mathrm{~F})$. The field observation made during months of attending different communitarian spaces reveals that not all people participate in the same way; there are some voices that are heard more than others. However, as we noted above, it is in the exercise of community involvement where people learn to speak in public, to agree, to think collectively, and communitarian leaders do not revoke these capabilities; on the contrary, they reinforce them.

Finally, we want to highlight another key issue: the importance of territory as a place that the community builds and from which the community is being built: the city we are building from our territories (C84F). The inhabitants of Comuna 8 perceive the city as 
the sum of different territories. These are spaces where relationships take place, where people build their individual and collective capabilities and exercise their agency. Therefore, it is important to defend it from other visions of the city, such as those of the public authorities, which do not understand the diversity and dynamics in which territories evolve.

The community becomes a planner: "territorial defence includes planning we do for ourselves [...] we are the architects, planners, topographers, surveyors who draw up our territory" (C84F). In this way, the community collectively builds their capability to plan the territory, which is another of the collective capabilities identified in this case. In addition, the territory acquires a symbolic value since it is associated with the memory process and the peace process: "if the territory is not defended, peace can not be built" $(\mathrm{C} 84 \mathrm{~F})$. These dimensions of the transformation of the territory are not reflected in official planning, which makes the distance that exists between the community demands and the local development policies even more evident.

\section{The case of the ZRC}

The individual capabilities that respondents identified in this case is very similar to Commune 8. Especially for people who have no formal studies, they highlighted that community participation provides an opportunity for personal growth and contributes towards them acquiring more instrumental skills, such as learning to solve problems or to apply for public resources. Remarkably, the women interviewed stressed the importance community participation has on increasing their self-esteem, gaining confidence, and being able to see themselves as agents of change: "women learn to value themselves as individuals, to be women leaders as they are at home, [we must] forget the fear that we cannot work with the community [...] that as a woman you are equally worthy, that your rights can be respected" (C7F). In this sense, participation in the community provides these women with the opportunity to gain individual agency.

Regarding the collective capabilities, as in Comuna 8, community participation creates the capability to carry out projects that are of interest to the whole community. The type of projects (the functionings) are oriented to the satisfaction of individual, family and collective needs of members of the community. These needs range from solving specific problems, such as being able to afford a funeral, to carrying out projects for the community, such as roads, schools, etc. 
No references were made to rights, but Cabrera's past, characterised by peasant resistance and struggles, gives the community a political identity: "despite not having been born here [...] struggles" (C7F). Two more components should be mentioned that make up the identity of a Cabreruna: working the land, and being linked to the ecosystem (C4F).

In Cabrera, as in Comuna 8, the combination of social and environmental conversion factors is paramount. On the one hand, their dissatisfaction with past and present public policy; on the other, the environmental awareness of the community, strongly influenced by its proximity to the el Páramo area of high ecological value. As one interviewee summed up: "public actors have a general model, they make development plans from a national model [...] they see us as competitors [...] the ZRC is as an agricultural model that is less aggressive for the soil, more harmonious with nature... [we use] techniques that are not solely based on being highly productive” (C5M).

The ZRC represents this triple identity of the community of Cabrera and, linked to this, we argue that there is another collective capability in Cabrera: to be able to imagine themselves as a community with this triple identity made of political struggles, agricultural production and environmental sustainability. Associated with that collective capability, we found another: the capability to realise that communitarian identity vision by planning, whose functionings are materialised in the formulation of the Sustainable Development Plan and in different productive projects based on agroecological farming developed in Cabrera.

The territory in the case of Cabrera is the ZRC itself, which is both a geographical and an identitarian feature. The difference with Comuna 8 is that the ZRC also enjoys legal recognition. The endowment (the territory of the ZRC) is enforced by a legal recognition (social conversion factor) enabling the inhabitants of Cabrera to expand their opportunities to implement their community vision. However, in practice, the community expresses some disappointment with the implementation of the ZRC. As noted by one interviewee: "the ZRC has not progressed due to the inactivity of the government $[\ldots]$ nor has the municipality shown much willingness $[. .$.$] when applied to$ the national territory, the policies are contradictory (machines, tractors, etc.) [...] which cause environmental degradation [...] the way they are providing technical assistance is not suitable" (C4F). 
What this quote reveals is that, as we explained when speaking of the Colombian context, the agro-industrial model is being imposed in the country as the vision of Colombian rural development. Undoubtedly, the model of the ZRC of Cabrera challenges that view and is, therefore, seen as a competitor and as a threat by the state. Similarly, another threat to maintaining the development vision of the ZRC is the seasonal arrival of new people who are not interested in the organisational process and are not aware of the concept of the ZRC, and therefore do not contribute to it, "Not all people are judicious enough to give this importance to the $Z R C$, we find new people in Cabrera, some who come sporadically at harvest time, who are not interested in the subject, and will never be interested in it" (C5M).

An important issue that is of great concern to community leaders is how to convey the values of the ZRC (what they call their triple identity) to Cabrera's youth. The young people participate in spaces where, together with producers, women and older adults, joint actions in the territory are discussed, debated and proposed. These spaces have enabled important foundations to be laid for the continuity and sustainability of the objectives and principles in which the project of the ZRC is framed. However, the transmission of identity to young people is seriously threatened by the migratory trend. The search for other urban lifestyles, opportunities and access to higher education, mean that the younger people move away to other places, lose their identity and do not contribute to the community strengthening of their territory, which is a constant fear of the Community leaders of Cabrera, "The only problem is that they study and then leave” (C6M).

Finally, the case of Cabrera also provides us with an example of collective agency. It is in the process of thinking about the community from these principles where collective agency is exercised. Other key principles are also stressed: "respect, teamwork, transparency, putting yourself in someone else's shoes" (C5M). We do not have enough evidence to assess the quality of this participation. Our interviewees say that there is a high degree of participation of people from different social organisations (women, traders, farmers, etc.). One of the most highly valued participation spaces are the Juntas de Acción Comunal (Community Action Boards) which are formally recognised by Colombian law as spaces where communities can participate in the decision-making process. In this case, unlike Comuna 8, where meaningful participation occurred in 
areas claimed by the community, in Cabrera an officially recognised space becomes a place that reinforces communitarian participation.

In Table 2, we summarise the main findings of our fieldwork in Comuna 8 and ZRC through the key elements of the capability approach. This help us to introduce the discussion of the next section.

\begin{tabular}{|c|c|c|}
\hline & Comuna 8 & ZRC \\
\hline $\begin{array}{l}\text { Individual } \\
\text { capabilities }\end{array}$ & $\begin{array}{l}\text { Being able to: } \\
\text { have a critical and } \\
\text { comprehensive reading of the } \\
\text { context; } \\
\text { share emotions and feelings. }\end{array}$ & $\begin{array}{l}\text { Being able to: } \\
\text { experience personal growth; } \\
\text { acquire instrumental skills; } \\
\text { increase self-esteem; } \\
\text { gain confidence and } \\
\text { individual agency. }\end{array}$ \\
\hline $\begin{array}{l}\text { Individual } \\
\text { functionings }\end{array}$ & $\begin{array}{l}\text { Increasing of autonomy self- } \\
\text { recognition as agents of change. }\end{array}$ & $\begin{array}{l}\text { Learning to solve problems } \\
\text { to apply for public resources. } \\
\text { See themselves as agents of change. }\end{array}$ \\
\hline $\begin{array}{l}\text { Collective } \\
\text { capabilities }\end{array}$ & $\begin{array}{l}\text { Being able to: } \\
\text { see themselves as political } \\
\text { subjects; } \\
\text { be in resistance; } \\
\text { plan and defend the territory. }\end{array}$ & $\begin{array}{l}\text { Being able to: } \\
\text { carry out projects that are of the } \\
\text { interest for the whole community; } \\
\text { imagine themselves as a community } \\
\text { with a triple identity made of } \\
\text { political struggles, agricultural } \\
\text { production and environmental } \\
\text { sustainability. }\end{array}$ \\
\hline $\begin{array}{l}\text { Collective } \\
\text { functionings }\end{array}$ & $\begin{array}{l}\text { Demand economic and social } \\
\text { rights. } \\
\text { Advocacy work. }\end{array}$ & $\begin{array}{l}\text { Elaborate projects. } \\
\text { Develop a communitarian identity. }\end{array}$ \\
\hline
\end{tabular}




\begin{tabular}{|l|l|l|}
\hline & $\begin{array}{l}\text { Promote social mobilisation. } \\
\text { Produce and influence their own } \\
\text { collective planning. }\end{array}$ & \\
\hline Collective agency & $\begin{array}{l}\text { Collective participation. } \\
\text { Collective definition of public } \\
\text { good. }\end{array}$ & $\begin{array}{l}\text { Collective thinking about the } \\
\text { community. }\end{array}$ \\
\hline Social conversion & $\begin{array}{l}\text { Governmental urban planning. } \\
\text { fymbolic and social value of the } \\
\text { territory. }\end{array}$ & $\begin{array}{l}\text { Dissatisfaction with past and } \\
\text { present public policy. } \\
\text { Agro-industrial model. } \\
\text { Legal recognition. }\end{array}$ \\
\hline $\begin{array}{l}\text { Environmental } \\
\text { conversion }\end{array}$ & $\begin{array}{l}\text { Mountainous characteristics. } \\
\text { Lack of means of transport and } \\
\text { physical infrastructure to connect } \\
\text { the different neighbourhoods } \\
\text { within Comuna 8. }\end{array}$ & $\begin{array}{l}\text { El Páramo area of high ecological } \\
\text { an identitarian feature. }\end{array}$ \\
\hline
\end{tabular}

Table 2: Main elements of the two communities

\section{Theoretical and empirical contributions of the two cases}

Both examples provide us with insights from the analysis of two different areas: the first is the contribution that the capability approach can make towards obtaining a better understanding of the community, complementing other approaches and approximations. In particular, we point out how the four key elements of the capability approach we used in the analysis (capabilities, functionings, social and environmental conversion factors and agency) can help us understand what people value most about their participation in the community, and what they can achieve with it, all of this being influenced by the social, political and geographical context.

However, at the same time, the case study can contribute to the literature of the capability approach, exemplifying the existence of collective capabilities and functionings and collective agency, as well as elements contributing to a better 
understanding of where and how agency is exercised. These contributions are examined in more detail in the following three sections.

How community involvement can contribute to individual and collective capabilities

The two cases illustrate what community participation means for community members: on a more individual level, valuable contributions on the emotional (better well-being, feeling more recognised, improved self-esteem) and cognitive level (having a more holistic and critical vision of the context) have been highlighted. All of these enable community members not only to make proposals, but also to increase their autonomy and even their self-recognition as political subjects. These are examples of individual capabilities obtained by participating in the community, in line with what Stewart (2005) and Sen (2002) proposed.

However, in both examples, we also find collective capabilities; capabilities that can only be developed from collective action: capabilities that can only be achieved socially ... as a result of social interaction (Comim and Carey, 2001 quoted in Ibrahim, 2006: 403). We have identified: the capability to see themselves as political subjects; the capability to be in resistance; the capability to imagine themselves as a community with their own identity; and the capability to realise their vision of communitarian identity through planning.

Both individual and collective capabilities are acquired in the various processes of community participation and interaction with public authorities. This is another key element to understand how capabilities are being configured. The two cases analysed provide a clear view of how the capabilities of the communities are affected by inaction, misuse, and different views of planning of the territory on the part of the state and local governments. However, at the same time, community action wants to transform and propose alternatives of intervention in the territory. We agree with Ibrahim that there is a two-way relationship between individual capabilities and social structure: "while social structures are instrumentally and intrinsically important for human capabilities, capabilities can also alter the pre-existing social structures rendering them more conducive to personal and communal well-being” (Ibrahim, 2006: 402). This interpretation is also valid for collective capabilities and, we argue, we need to add the 
geographical dimension. The communities conceive themselves as existing in a geographical area (the slopes of Comuna 8 or the ZRC near the Páramo of Cabrera), which undoubtedly shapes their capabilities.

\section{Collective functionings: a capability understanding of collective planning}

Another contribution we want to emphasise are the functionings derived from collective community action we have seen represented in different communitarian planning exercises. These examples clearly depict how the visions of planning imposed by the authorities do not take into account the potential of people as agents of change, nor focus on obtaining the results that people value (Alkire, 2002; Frediani, Boni and Gasper, 2014). A community planning approach consistent with the capability approach should respect their collective capabilities and their materialisation in the form of community planning as the road map for identifying areas for policy programming and implementation (Biggeri and Ferrannini, 2014).

The two case studies not only illustrate the importance of planning from the perspective of communities, but also how this planning must take into account the social and environmental conversion factors. The strategies adopted by the two communities are different: the ZRC opts for a sustainable peasant-based production model, while Comuna 8 proposes the guarantee of three rights: housing, to remain in the territory, and respect for the diversity of habitat forms. Both communities provide us with the crucial value of community participation, which is non-negotiable, but Cabrera uses the ZRC's legal figure to make its plans, while Comuna 8 disputes the legal vision of the territory. Also, in both cases, the historical perspective is essential. You cannot understand their plans without resorting to historical memory, the past peasant struggles of Cabrera, and the various community exercises to inhabit the slopes of the Commune 8 in a context of violence and lack of the most basic human rights. In short, these two cases reinforce the importance of properly reading the context, being aware of different dynamics, and incorporating a historical and geographical perspective in planning.

\section{How and where collective agency is exercised}


We believe that the two cases also illustrate the existence of collective agency and how and where it is exercised. According to Crocker and Robeyns (2009), the exercise of agency requires 1) Self-determination: the person decides for himself or herself rather than someone or something else making the decision; 2) Reason orientation and deliberation: the person bases his or her decisions on reasons such as the pursuit of her aspirations and goals; 3) Action: the person performs or has a role in performing; 4) Impact in the world: the person brings about (or contributes to bringing change in the world). Deneulin and Alkire $(2009,37)$ add two more components to this ideal of agency: a person who exercises agency can pursue well-being or other objectives that should somehow be reasonable (this component is also emphasised by Drydyk, 2013), plus they emphasise the responsibility of the agent in wanting to achieve her goals, so that agency is linked to responsible choices and actions.

The two cases illustrate how community members exercise their agency in the processes of community participation, especially in community planning exercises. There are processes of collective deliberation, collective thinking, actions are designed and carried out, and these are designed to bring about a change that aims towards communitarian well-being or other objectives that can be considered reasonable for the common good. There is also a great sense of responsibility in trying to achieve the objectives and in the processes of deliberation and decision-making, this responsibility is reinforced.

Is it individual or collective agency? We believe that if communities can be the subject of collective capabilities they can also be subjects of collective agency. If having agency is being an actor of change, the cases illustrate that being part of the community entitles them to be change makers at another level that they cannot reach on an individual level. The two communitarian Plans are materialisations of collective agency. Individually, they would not have been possible.

Obviously, participation is not equal for all people. We have seen how some people have a greater leadership role. However, this is intrinsic to the dynamics of participation and a more detailed analysis of power dynamics within the two communities could provide the keys to understanding the limits of community participation and, therefore, the exercise of agency.

Another interesting element that the two cases illustrate is the kind of spaces where collective agency is exercised. In the case of Comuna 8, agency is exercised in an area claimed by the community. This type of space, according to Gaventa (2006), is a "claimed" space where less powerful actors can infiltrate the political scene and demand 
some influence. In the case of the ZRC, agency is exercised in the Community Action Boards, which are places recognised by Colombian law as places for community involvement in decision-making. Comuna 8 also has Community Action Boards, but they believe that these spaces are co-opted by the authorities and do not respond to the idea of community participation they demand. They are seen as "invited" spaces, where the type of decision-making is defined by authorities.

\section{Conclusions}

The analysis of the two Colombian communities using elements of the capability approach has allowed us, on the one hand, to obtain a better understanding of what people value as members of community. We have also been able to observe how community participation gives real opportunities to the community to be and do what is really valued collectively. It confirms, therefore, the existence of collective capabilities that are more than the sum of individual capabilities.

Moreover, we have examined the functionings that this community participation produces. In particular, we have focused on community planning materialised through two community plans developed in Comuna 8 and the ZRC. This view of planning corresponds to the principles of the capability approach since they reflect the communitarian visions and are developed in a participatory way. Due to the limitations of this research, we were unable to look into the internal dynamics of community participation, which would require a more in-depth analysis.

In the analysis of capabilities and functionings, it is essential to consider social and environmental conversion factors. Among the former were public policies on housing and land planning (Comuna 8) and rural development (ZRC). The two communities challenge public policy, in different ways and in different areas. Also the geographic space has proved to be a key driver. For Comuna 8, territory is the key to understanding how the community is perceived and how its members want to act in order to transform it. In the ZRC, due to its proximity to an ecological reserve, its community has a strong ecological consciousness that permeates its development vision. Finally, the historical perspective is also key to understanding the capabilities and functionings of the two communities. The fact that the communities are in resistance is the result of more than fifty years of conflicting relations between public and private actors. 
Finally, research has shed light on the individual agency that promotes community participation and the exercise of collective agency. This not only occurs in spaces recognised by Colombian law, but also in areas claimed by the communities themselves.

\section{References}

AI (Amnesty International) (2016) 2015/16 Report, Amnesty International: London.

Alkire, S. 2002. Valuing Freedoms: Sen's Capability Approach and Poverty Reduction.

Oxford: Oxford University Press.

Belda-Miquel, S. A. Boni Aristizábal and M.F. Sañudo Pazos, 2016, Hacia una cooperación internacional transformadora: Solidaridades y aprendizajes con movimientos sociales por los derechos humanos en Colombia, Icaria: Barcelona.

Biggeri, M., and A. Ferrannini. 2014. "Opportunity Gap Analysis: Procedures and Methods for Applying the Capability Approach in Development Initiatives." Journal of Human Development and Capabilities A Multi-Disciplinary Journal for PeopleCentered Development 15 (1) 60-78.

Boni, A. and Walker, M., (2016). Universities and Global Human Development. Theoretical and empirical insights for social change. Routledge Sustainability Series, London.

CINEP (2012), Minería, conflictos sociales y violación de derechos humanos en Colombia, CINEP: Bogotá.

Comim, F. and Carey, F. (2001) 'Social capital and the Capability Approach: are Putnam and en incompatible bedfellows?', paper presented at the EAEPE Conference 'Comparing Economic Institutions', Siena, November.

Cortina, A. (2005). Alianza y Contrato. Madrid: Editorial Trotta.

Crocker, D, and I Robeyns. 2009. "Capability and Agency." In Amartya Sen, Contemporary Philosophy in Focus, edited by C J. Morris, 60-90. Oxford: Oxford University Press.

Drydyk, J. 2013. "Empowerment, Agency and Power." Journal of Global Ethics 9(3): 249-62.

A. A. Frediani, Boni, A. and D. Gasper (2014) "Approaching Development Projects from a Human Development and Capability Perspective", Journal of Human 
Development and Capabilities: A Multi-Disciplinary Journal for People-Centered Development, 15:1, 1-12.

J. Gaventa, (2006) "Finding Spaces for Change. A Power Analysis." IDS Bulletin 37(6): $23-33$.

Greenwood, T. (2016) The problem with risk in Medellín in https://medellinsocial.wordpress.com/2016/09/28/the-problem-with-risk-in-medellin in [retrieved 26th October 2016]

Hill, J. (1996). Psychological sense of community: Suggestions for future research Journal of Community Psychology, 24, 431-438.

Ibrahim, S., 2006. From Individual to Collective Capabilities: The Capability Approach as a Conceptual Framework for Self-help. Journal of Human Development and Capabilities: A Multi-Disciplinary Journal for People-Centered Development, 7, pp. $397-416$.

Lo Biondo, G. (1999). Algunos elementos del aporte de Bernard Lonergan a la política. in: J. Scanonne \& V. Santuc (comp.), Lo político en América Latina (pp. 281-302). Bs. As.: Editorial Bonum.

Massé, F. and Camargo, J. (2012), Actores Armados Ilegales y Sector Extractivo en Colombia: V Informe. Observatorio Internacional DDR - Justicia y Paz: Bogotá.

Maya Jariego, I. (2004). Sentido de comunidad y potenciación comunitaria. Apuntes de Psicología, 22(2), 187-211.Colegio oficial de Psicología de Andalucía OccidentalUniversidad de Sevilla

McMillan \& Chavis (1986) Sense of community: A definition and theory. Journal of Community Psychology, 14(1), 6-23.

Ramos-Vidal and I. Maya-Jariego / Sentido de comunidad, empoderamiento psicológico y participación ciudadana en trabajadores de organizaciones culturales Psychosocial Intervention 23 (2014) 169-176

Robeyns, I. (2005) The Capability Approach: a theoretical survey. Journal of Human Development and Capabilities, 6,1, pp. 93-104 Robeyns, I. (2016) Capabilitarianism. Journal of Human Development and Capabilities, 6(1), 397-414.

Sarason, S. B. (1974). The psychological sense of community: prospects for a community psychology. San Franscisco: Jossey Bass.

Sen, A. (1999) Development as freedom, Oxford: Oxford University Press. 
Sen, A. (2002) 'Response to commentaries', Studies in Comparative International Development, 37(2), pp. 78-86.

SINPEAGRICUN - ILSA - INCODER (2013). Plan de Desarrollo Sostenible Zona de Reserva Campesina de Cabrera (Cundinamarca). Por una Zona de Reserva Campesina garante de derechos económicos, sociales, culturales y ambientales para los cabrerunos. Bogotá: Sindicato de Pequeños Agricultores de Cundinamarca, Instituto Latinoamericano para una Sociedad y un Derecho Alternativos \& Instituto Colombiano de Desarrollo Rural. Avaliable at http://www.ilsa.org.co:81/node/696 [retrieved 4th October 2016].

G. Tonon, Young People's Quality of Life and Construction of Citizenship, Springer Briefs in Well-Being and Quality of Life Research, pp. 21-31.

DOI: 10.1007/978-94-007-2996-4_3.

Stewart, F. (2005) 'Groups and capabilities', Journal of Human Development, 6(2), pp. $185-204$.

UNIDAD DE PLANEACIÓN MINERO-ENERGÉTICA (2012), Plan Nacional de Desarrollo Minero al 2014. Bogotá: UPME.

Velandia, B. C. (2015). Luchas Campesinas y resistencia frente a los conflictos ambientales e la Zona de Reserva Campesina de Cabrera Cundinamarca: Una alternativa territorial para la Paz, Polisemia. 43-58. 